\title{
ORGANIZATION OF HEALTH ENVIRONMENT IN THE AGRICULTURAL UNIVERSITY
}

Petrenko Natalia, senior lecturer in physical education, Mykolayiv National Agrarian University, 9 Georgiy Gongadze Str., 54020 Mykolayiv, Ukraine, nata.petrenko.65@mail.ru

The main purpose of improving higher education in Ukraine is achieving a fundamentally new quality level training graduate school. Today, scholars, practitioners, employers are concerned of too high volume of knowledge, that students get, and the lack of practical skills and the skills of graduates of universities follow the received knowledge, apply them in practice. Solving these problems largely depends on scientific and pedagogical workers, who directly provide the success of higher education institutions in the training of future specialists. In addition, they have to satisfy modern requirements of the Organization of the educational process in higher education, that are aimed at improving the quality of training specialists with higher education is only a teacher of the formed pedagogical competence.

The article discusses the health-environment as one of the conditions for the development of pedagogical competence; training of specialists and masters of the agrarian sector is seen as an important component of professional competence of the future expert; provided specific forms of training future farmers, as an example of using different methods to practical lessons regarding the organization of health-friendly environment. Healthy lifestyle of students, health and health-friendly environment are the main components of the training of students of the Agrarian University. The purpose of the article is to reveal the basic aspects of health-friendly environment specialist in agricultural industry.

Keywords: ecology; genetically modified organisms; health-environment; healthy lifestyle; public health; school health activities.

Стаття надійшла до редакції 23.03.2017

Прийнято до друку 25.05.2017

УДК $378:[37.011 .3: 78]: 785$

Іван Касілов

ORCID iD 0000-0002-0368-1169

викладач кафедри музикознавства, інструментальної та хореографічної підготовки, Криворізький державний педагогічний університет, пр-т Гагаріна, 54, 50086 м. Кривий Ріг, Україна kasilov1980@i.ua

\section{СПЕЦИФІКА ПРОФЕСІЙНОЇ ПІДГОТОВКИ МАЙБУТНІХ УЧИТЕЛІВ МУЗИЧНОГО МИСТЕЦТВА ДО ІНСТРУМЕНТАЛЬНО-ВИКОНАВСЬКОЇ ДІЯЛЬНОСТІ}

Устаттірозкриваються основніпроблеми професійноїпідготовки майбутніхучителів музичногомистецтва до інструментально-виконавської діяльності в умовах вищої педагогічної освіти в Україні. Розглядається сутність поняття інструментально-виконавської діяльності в наукових роботах відомих зарубіжнх та вітчизняних учених. Визначаються основні специфічні риси, які відповідають за структуру інструментальновиконавської діяльності при вивченні спещіальних дисциплін з основного та додаткового інструментів у процесі навчання на факультетах мистецтв педагогічних університетів.

Ключові слова: виконавець; інструментально-виконавська діяльність; музичний інструмент; навчальний процес; професійна підготовка; специфічні риси; учитель музичного мистецтва.

Вступ. Соціально-економічний розвиток та приєднання України до Болонської угоди зумовило значних змін у процесі педагогічної освіти сьогодення. Розбудова нашого суспільства на демократичних засадах вимагає поступового переходу від традиційного до особистісно-зорієнтованого навчання, суть якого полягає у спрямуванні на індивідуально-психологічні властивості кожної особистості. Модернізація сучасної вищої освіти відобразилася також на умовах формування педагогічних кадрів, зокрема на професійній підготовці майбутніх вчителів музичного мистецтва. Професія вчителя музичного мистецтва є багатовекторною за своєю специфікою та 
передбачає комплексне поєднання різноманітних видів професійної діяльності, однією з яких є інструментально-виконавська діяльність вчителя музичного мистецтва, визначення якої стало предметом нашого наукового дослідження. Проблемі дослідження інструментально-виконавської діяльності на наукових засадах приділяли свою увагу ряд відомих зарубіжних та вітчизняних вчених як Е. Б. Абдуллін, Ю. Б. Алієв, Л. О. Безбородова, В. В. Бурназова, Л. В. Гусейнова. Д. Д. Елліот, Н. В. Лаврентьєва, С. Х. Маргуліс, Н. Г. Мозгальова, О. М. Олексюк, О. С. Плохотнюк та багато інших. Таким чином, ми вважаємо за необхідне розглянути структуру інструментально-виконавської діяльності майбутніх вчителів музичного мистецтва у науковопедагогічній теорії та визначити її специфіку.

Мета статті - визначення специфічних рис інструментально-виконавської діяльності в процесі професійної підготовки майбутніх вчителів музичного мистецтва.

Сучасний стан сформованості інструментальновиконавської діяльності як педагогічна проблема. Погляди на структуру інструментальновиконавської діяльності майбутнього вчителя музичного мистецтва у педагогічній теорії є доволі різноманітними, тому розуміння даної проблеми носить варіативний характер. Однак слід зазначити на тому, що є загальні моменти, на проблемі яких автори найбільше зосереджують свою увагу.

При дослідженні структурних компонентів музичних творів як акустичного явища, американська вчена Є. Х. Маргуліс вивчала музичний матеріал на основі показників емоційної реакції слухацької аудиторії на повторення музичного матеріалу. Акцентуючи свою увагу на багатократному повторенні звуків однієї висоти, вчена доводить, що однакових асоціацій у природі сприйняття не iснує (Margulis E., 2012). Таким чином Е. Х. Маргуліс вказує на динамічність розвитку процесу звучання у часовому просторі. Аналізуючи проблему інструментально-виконавської діяльності в умовах початкової школи, автори Л. О. Безбородова та Ю. Б. Алієв у своєму методичному посібнику акцентують на необхідності розвитку наступних творчих здібностей учнів, а саме: вміння імпровізувати на елементарних музичних інструментах; знаходити власні ритми та мелодії; створювати акомпанемент до пісень та виконувати нескладні п'єси (Безбородова Л. А., Алиев Ю. Б., 2002, с. 215). Таким чином автори наголошують на тому, що реалізація творчих завдань під час опанування грою на дитячих музичних інструментах вимагають від майбутнього вчителя музичного мистецтва таких знань як індивідуальні характеристики та технічні можливості окремих музичних інструментів, володіння специфічними виконавськими прийомами гри на них (Безбородова Л. А., Алиев Ю. Б., 2002, с. 217). У своїх наукових дослідженнях з музичної педагогіки О. М. Олексюк розглядає музично-виконавську діяльність як окрему складову професійної діяльності педагога-музиканта, що проявляється у двох аспектах виконавського процесу виконанні та інтерпретації, де виконавець виступає як творець нових художніх цінностей (Олексюк О. М., 2006, с. 168-169), цілком очевидно, що вчена доводить необхідність розуміння інструментально-виконавської діяльності як творчої концепції.

Інструментально-виконавську діяльність на основі розвитку процесів мислення було розглянуто у роботах Н. Г. Мозгальової (Мозгальова Н. Г., 2002, с. 10) та Н. В. Лаврентьєвої (Лаврентьєва Н. В., 2016, c. 5). Тож, на основі аналізу попередніх досліджень ми можемо спостерігати тенденцію до посилення уваги на інструментально-виконавську діяльність в умовах музично-педагогічної освіти а також визначити власну концепцію інструментально-виконавської діяльності майбутнього вчителя музичного мистецтва, яка характеризується наявністю необхідних професійних знань, умінь та навичок, спрямованих на професійне опанування музичним інструментом та використанням його у процесі професійної підготовки майбутнього вчителя музичного мистецтва, у організаційно-просвітницьких заходах 3 музичного мистецтва (концерти, фестивалі, конкурси, лекції-концерти, творчі вечори тощо). Таким чином, ми бачимо, що інструментально-виконавська діяльність майбутнього вчителя музичного мистецтва $є$ комплексним багатовекторним поняттям, що складається з великої кількості специфічних рис та потребує детального теоретичного обгрунтування у педагогічній теоріі.

Характеризуючи вокально-педагогічну діяльність вчителів музичного мистецтва, Н. А. Овчаренко визначає наступні специфічні риси: західноєвропейська та вітчизняна традиція в і1і основі; опора на психофізіологічний компонент; художньо-творча сутність; особлива мова вокального мистецтва, що має свої закономірності існування й розвитку; гармонійне поєднання інтелектуального та емоційного у ii здійсненні; педагогічна спрямованість у формуванні вокально-мистецьких цінностей учнів; постійне самовдосконалення; багатокомпонентність структури (Овчаренко Н. А., 2016, с. 91). Згідно поставлених завдань нашого наукового дослідження, ми визначаємо наступні специфічні риси, які характеризують специфіку професійної підготовки майбутніх учителів музичного мистецтва до інструментальновиконавської діяльності. До таких специфічних рис ми відносимо: визначення фізіологічних характеристик інструменталіста-виконавця та особливостей будови виконавського апарату; послідовне ускладнення репертуару як необхідна закономірність художньо-технічного розвитку інструменталіставиконавця; орієнтація на жанрово-стильове спрямування у професійній підготовці інструменталіставиконавця; формування поліфонічного мислення у інструменталіста-виконавця; систематичність занять за музичним інструментом. 
Визначення фізіологічних характеристик інструменталіста-виконавия та особливостей будови виконавсъкого апарату. Дане питання є важливою специфічною рисою у професійній підготовці майбутнього вчителя музичного мистецтва до інструментально-виконавської діяльності. Актуальність даного питання обумовлена, насамперед, індивідуальними характеристиками психічного та фізичного розвитку людини, вираженими у вигляді iii психофізіологічних показників, які мають значний вплив на процес виконання на музичному інструменті а також безпосереднім контактом виконавця з музичним інструментом взагалі. Для досягнення максимальної ефективності у процесі виконання на музичному інструменті необхідна чітка координація та організованість відповідних нервово-м'язових функцій виконавського апарату інструменталіста-виконавця. Організація таких функцій полягає, насамперед, у звільненні виконавського апарату від напруження у рухових діях. Як зазначає у своїх дослідженнях відомий гітаристпедагог М. П. Михайленко, секрет технічної майстерності полягає у налагодженій координації ігрових рухів а також у керівництві зусиллями обох рук, фокусуванням та зведенням до мінімуму витрат м'язової енергії, яка є необхідною для вирішення суто музичних завдань (Михайленко М. П., 2003, с. 218). В. В. Бурназова зазначає, що мистецтво керування виконавським апаратом та музичним інструментом становить основу музичновиконавської компетентності, яка відповідає за вирішення художньо-технічних завдань у процесі виконання (Бурназова В. В., 2012, с. 19-21).

Мистецтво керування процесами напруження та розслаблення м'язів полягає у систематизації використання підготовлених та робочих рухів виконавського апарату у процесі виконання на музичному інструменті (Касілов І. А., 2015, с. 12-17). Під поняттям підготовлених рухів виконавського апарату слід розуміти процес механічної дії пальців правої та лівої руки безпосередньо перед утворенням звуку у процесі виконання на музичному інструменті. Закономірність використання підготовленого руху полягає у створенні необхідних умов для максимального скорочення м'язових витрат у рухових діях правої та лівої рук. За допомогою таких рухів виконавець-інструменталіст розслаблює м'язи виконавського апарату, що є необхідною передумовою для концентрації зусиль на попереднє здійснення робочого руху, який відповідає за якість звукоутворення у процесі виконання на музичному інструменті (Касілов I. А., 2015, с. 16-17). Під поняттям робочих рухів слід розуміти сам процес звукоутворення, який представляє собою комплекс рухових дій як правої так і лівої рук одночасно (Касілов I. А., 2015, с. 17).

Виходячи з вищесказаного ми можемо зробити наступний висновок, що постійний контроль за координацією рухів у процесі контактування виконавця з музичним інструментом буде сприя- ти підвищенню ефективності виконавської майстерності майбутнього вчителя музичного мистецтва у його інструментально-виконавській діяльності.

Послідовне ускладнення репертуару як необхідна закономірність художньо-технічного розвитку інструменталіста-виконавия. Урахування цієї специфічної риси має особливе значення у професійній підготовці майбутнього вчителя музичного мистецтва до інструментально-виконавської діяльності. Ї̈̈ суть полягає у забезпеченні необхідних умов для протікання правильного розвитку, спрямованого на формування виконавських навиків гри на музичному інструменті. Слід зазначити, що формування виконавських навиків має суто індивідуальний характер. Як зазначає Л. В. Гусейнова, інструментально-виконавська діяльність розглядається як цілеспрямований процес реалізації власних творчих якостей музиканта, що відображаються у індивідуальному виконавському досвіді під час виконання на інструменті (Гусейнова Л. В., 2011, с. 61-62). Для забезпечення таких умов необхідно чітко розуміти поетапність формування відповідних знань, вмінь та навиків, які вельми необхідні для правильного формування виконавської майстерності інструменталіста як майбутнього вчителя музичного мистецтва. При аналізі програмних вимог інструменталіста-виконавця М. П. Михайленко наголошує на важливості включення в учбовий репертуар інструменталіста музичних творів малої форми, поліфонічних творів та творів великої форми, опанування яких повинно будуватися за принципом поступового ускладнення (Михайленко М. П., 2003, с. 127-133).

Необхідність ознайомлення з музичними творами малої форми на початкових етапах навчання на музичному інструменті обумовлена, поперед усім. орієнтацією на верхній голос - мелодію, яка виражає головну ідею музичного твору та являється основою його художньо-образного змісту. Вивчення музичних творів поліфонічного складу вимагає від студента факультету мистецтв високого рівня слухового контролю та достатньої теоретичної підготовки, тому як прослуховування декількох голосів у фактурі музичного твору потребує розподілення уваги студента а також аналітичного підходу до процесу виконання на музичному інструменті. Робота над музичними творами крупної форми побудована на основі контрасту, що викликаний наявністю головної та побічної партії, контрастних частин, тому такі твори потребують швидкого емоційного переключення студента у виконавському процесі.

Таким чином, поступове ускладнення музичного репертуару в процесі опанування грою на музичному інструменті являє собою закономірність, яка обумовлена необхідністю формування психофізіологічних характеристик інструменталіста-виконавця у поєднанні з проблемними завданнями, що потребують відповідної теоретичної та практичної підготовки у процесі навчання. 
Орієнтація на жанрово-стильове спрямування у професійній підготовці інструменталіставиконавия. Обов'язковою передумовою розвитку інструменталіста-виконавця у процесі його професійної підготовки є врахування особливостей жанру та стильового спрямування музичного твору в процесі його розучування на музичному інструменті, що значно допоможе віднайти необхідні засоби задля реалізації головної мети, a саме: встановити, відтворити та передати художній образ у процесі виконання на музичному інструменті. Орієнтація на жанрово-стильове спрямування в інструментальній музиці вимагає високого рівня теоретичної та практичної підготовки. На думку відомого вченого Е. Б. Абдулліна, аналіз інструментально-виконавської діяльності у музичному мистецтві передбачає врахування таких аспектів як визначення конструкції музичної форми твору у виконавському процесі та врахування інтонаційної природи фразування (Абдуллин Э. Б., 1990 , с. 82). Наголошуючи на креативності вчителя музичного мистецтва, відомий американський дослідник Д. Д. Елліот акцентує свою увагу на формуванні його загальної компетентності у проблемних питаннях щодо розуміння стилістики та принципів функціонування музичних жанрів (Elliott D. J.). Як ми бачимо, автори акцентують свою увагу на детальному аналізі музичного твору, здійснення якого вимагає від інструменталіставиконавця значної теоретичної підготовки, зокрема вивчення елементів структури музичних форм.

При розгляді інструментальних музичних форм слід зазначити, що вони умовно поділяються на три самостійні групи: концертні форми; циклічні форми (сонати, симфонії, сюїти, партіти); самостійні інструментальні форми (прелюдії, фантазії, річеркари, т’єнто, канцони, токати, поеми, капріччіо, мініатюри та інші). Основною рисою усіх інструментальних музичних форм, на відміну від вокальних та хорових жанрів, є відсутність літературного тексту та безпосередня орієнтація виконавця на суто інструментальні прийоми та засоби інструментальної музичної виразності, урахування яких у процесі виконання допоможе формуванню художнього образу як головної передумови в музичному мистецтві.

Виходячи з цього, ми бачимо, що орієнтація на жанрово-стильове спрямування інструменталіставиконавця у навчальному процесі передбачає оволодіння основними теоретичними знаннями щодо закономірностей побудови музичних форм та їх детального аналізу а також встановлення логічних взаємозв'язків у визначенні лінії драматичного розвитку музичного твору.

Формування поліфонічного мислення у інструменталіста-виконавия. Важливе місце в структурі інструментально-виконавської діяльності майбутнього вчителя музичного мистецтва належить його теоретичній та практичній підготовці у процесі на- вчання, що спрямовані на розвиток поліфонічного мислення. Аналізуючи діяльність вчителя музичного мистецтва у процесі роботи з поліфонічними творами, М. I. Ройтерштейн у своїх дослідженнях висуває ряд вимог, які відповідають за професійну компетентність вчителя музичного мистецтва щодо роботи 3 поліфонічними творами, а саме: ознайомлення з гомофонним складом та його видами (Ройтерштейн М. И., 1988, с. 5-11); ознайомлення з підголосковою поліфонією (Ройтерштейн М. И., 1988, с. 19-56); ознайомлення 3 контрастною поліфонією (Ройтерштейн М. И., 1988, с. 57-96); ознайомлення 3 імітаційною поліфонією (Ройтерштейн М. И., 1988, с. 96-148). Таким чином, ми бачимо, що ознайомлення вчителя музичного мистецтва з вищеназваними видами поліфонічного складу є необхідною передумовою для розвитку поліфонічного мислення під час виконання на музичному інструменті а також буде забезпечувати наявність у нього відповідних знань, вмінь та навиків, необхідних для здійснення подальшої професійної діяльності.

Систематичність занять за музичним інструментом. Виховання систематичності у заняттях на музичному інструменті сприяє формуванню у виконавця необхідних знань та навичок, що відповідають за якість виконання музичного твору на інструменті, готовність інструменталіста до виконання музичного твору на сцені а також за спорідненість у контакті інструменталіста з самим музичним інструментом, яке у виконавській практиці досить часто використовується словосполученням «відчуття інструменту». Наголошуючи на необхідності систематичних занять у класі основного інструменту, О. С. Плохотнюк у своїх наукових дослідженнях звертає увагу на безперервному процесі становлення та постійного вдосконалення музикантом своїх виконавських можливостей, залученні майбутнього фахівця у концертну практику тощо (Плохотнюк О. С., 2016, с. 68). Від систематичних занять на музичному інструменті залежать такі аспекти виконавської майстерності як координація та синхронність рухів виконавського апарату, технічне вдосконалення під час гри на музичному інструменті, свобода виконавських рухів під час виконання музичного твору, організованість до конкретних виконавських дій та їх правильної послідовності. Недотримання систематичності занять на музичному інструменті доволі часто може викликати перевтому виконавського апарату та розвиток різноманітних його захворювань, зокрема тендовагініту та ганглій, які виникають від перенапруження, спричиненого відсутністю регулярних заняттях на музичному інструменті.

Виходячи з вищесказаного ми бачимо, що систематичність у заняттях на музичному інструменті може негативно відобразитися не лише на художньо-технічній стороні інструментально-виконавської діяльності а й на загальному стані здоров’я 
інструменталіста, тому як збільшення навантаження на виконавський апарат після тривалої паузи у заняттях може спричинити загальну перевтому а у деяких випадках сприяти розвитку професійного захворювання виконавського апарату.

Висновки. Врахування специфічних рис інструментально-виконавської діяльності професійного музиканта-педагога забезпечить значне підвищення рівня ефективності освітнього процесу на факультеті мистецтв, а також допоможуть у вирішенні проблемних питань інструментально- виконавського характеру, що значно покращить процес розуміння мови музичного мистецтва.

Таким чином, ми вважаємо за необхідне розробити чітку програму щодо підвищення якості професійної підготовки майбутніх учителів музичного мистецтва до інструментально-виконавської діяльності на основі впровадження в освітній процес необхідних педагогічних технологій, розробка яких буде спрямована на удосконалення сучасного стану інструментально-виконавської діяльності.

\section{Література}

1. Абдуллин Э. Б. Методологический анализ проблем музыкальной педагогики в системе вузовского образования / Э. Б. Абдуллин. - Москва : Прометей (МГПУ), 1990. - 188 с.

2. Безбородова Л. А. Методика преподавания музыки в общеобразовательных учреждениях : учеб. пособие для студентов / Л. А. Безбородова, Ю. Б. Алиев. - Москва : Издательский центр «Академия», 2002. - 416 с.

3. Бурназова В. В. Професійна компетентність музиканта-інструменталіста: зміст, структура, методи розвитку / В. В. Бурназова // Наукові записки [зб. наук. пр. за ред. І. Т. Богданова]. - Бердянськ : Бердянський державний педагогічний університет, 2012. - Вип. 3. - С. 16 - 22.

4. Гусейнова Л.В.Готовність до інструментально-виконавської діяльності: структурний аналіз / Л. В. Гусейнова // Науковий вісник Глухівського національного педагогічного університету ім. О. Довженка [зб. наук. пр. за ред. О. І. Курка]. - Глухів, 2011. - Вип.18. - С. 60 - 63.

5. Касілов I. А. Розвиток виконавської техніки студентів-гітаристів у процесі навчання на факультеті мистецтв / I. А. Касілов // Педагогіка вищої та середньої школи [зб. наук. пр. за ред. З. П. Бакум]. - Кривий Ріг : Криворізький педагогічний інститут ДВНЗ «КНУ», 2015. - Вип. 45. - С. 12 - 17.

6. Лаврентьєва Н. В. Формування творчого мислення майбутнього вчителя музичного мистецтва в процесі інструментально-виконавської підготовки : автореф. дис. ... канд. пед. наук : спец. 13. 00. 02 «Теорія та методика музичного навчання» / Н. В. Лаврентьєва. - Київ, 2016. - 21 с.

7. Михайленко М. П. Методика викладання гри на шестиструнній гітарі / М. П. Михайленко. - Київ : Книга, 2003. - 248 с.

8. Мозгальова Н. Г. Формування музичного мислення майбутнього вчителя музики в процесі інструментальної підготовки : автореф. дис. ... канд. пед. наук : спец. 13. 00. 02 «Теорія та методика навчання музики і музичного виховання» / Н. Г. Мозгальова. - Київ, 2002. - 18 с.

9. Овчаренко Н. А. Теоретико-методологічні засади професійної підготовки вчителів музичного мистецтва до вокально-педагогічної діяльності : дис. ... д-ра пед. наук : спец. 13.00.04 «Теорія і методика професійної освіти» / Н. А. Овчаренко. - Кривий Ріг : 2016. - 547 с.

10. Олексюк О. М. Музична педагогіка : навчальний посібник / О. М. Олексюк. - Київ : КНУКІМ, 2006. - $188 \mathrm{c}$.

11. Плохотнюк О. С. Визначення педагогічних умов формування професійно-ціннісних орієнтацій студентів мистецько-педагогічних спеціальностей у процесі музично-виконавської діяльності / О. С. Плохотнюк // Наукові записки [зб. наук. пр. за ред. В. Ф. Черкасова]. - Кіровоград : вісник Кіровоградського державного педагогічного університету ім. В. Винниченка, - 2016. - Вип.143. - С. 66 - 70.

12. Ройтерштейн М. И. Практическая полифония: учеб. пособие для студентов пед. институтов по спец. № 2119 «Музыка» / М. И. Ройтерштейн. - Москва: Просвещение, 1988. - 158 с. : ил.

13. Elliott D. J. Musical Creativity (Comments to Praxial Music) [online] / D. J. Elliott. - Available from : http : // www.davidelliottmusic.com/praxial-music-education/musical-creativity

14. Margulis E. (2012). Musical Repetition Detection Across Multiple Exposures / E. Margulis // Music Perception : Ann Interdisciplinary Journal, 29 (4), 2012. - pp. 377 - 385, DOI:10.1525 / mp.2012.29.4.377 (eng).

\section{References}

1. Abdullin E'. B. (1990). Metodologicheskij analiz problem muzy'kal'noj pedagogiki v sisteme vuzovskogo obrazovaniya [Metodological analysis of musical pedagogy in the system of higher education]. Moskva : Prometej (MGPU), 188 (rus).

2. Bezborodova L. A., Aliev Yu. B. (2002). Metodika prepodavaniya muzy'ki v obshheobrazovatel'ny'h uchrezhdeniyah [Methodology of music's teaching at the compulsory institutions]. Moskva : Izdatel'skij centr «kademiya», 416 (rus).

3. Burnazova V. V. (2012). Profesiina kompetentnist muzykanta-instrumentalista: zmist, struktura, metody rozvytku [Professional competence of musician-instrumentalist : content, structure, methods of development]. Scientific Notes of Berdiansk State Pedagogical University, (3), Berdiansk, 16 - 22 (ukr). 
4. Huseinova L. V. (2011). Hotovnist do instrumentalno-vykonavskoi diialnosti: strukturnyi analiz [Readiness to instrumental-performing activity : structural analysis]. Scientific Bulletin of Hlukhiv National Pedagogical University, (18), Hlukhiv, 60 - 63 (ukr).

5. Kasilov I. A. (2015). Rozvytok vykonavskoi tekhniky studentiv-hitarystiv u protsesi navchannia na fakulteti mystetstv [Development of student's performance abilities in learning guitar at the faculty of Arts]. Pedagogy of Higher and Secondary School, (45), Kryvyi Rih, 12 - 17 (ukr).

6. Lavrentieva N. V. (2016). Formuvannia tvorchoho myslennia maibutnoho vchytelia muzychnoho mystetstva $\mathrm{v}$ protsesi instrumentalno-vykonavskoi pidhotovky [Formation of creative thinking of the future music's teacher in the instrumental performance training] : Extended abstract of candidate's thesis : 13. 00. 02. Kyiv, 21 (ukr).

7. Mykhailenko M. P. (2003). Metodyka vykladannia hry na shestystrunnii hitari [Methodology teaching by playing the six-string guitar]. Kyiv : Knyha, 248 (ukr).

8. Mozghalova N. H. (2002). Formuvannia muzychnoho myslennia maibutnoho vchytelia muzyky v protsesi instrumentalnoi pidhotovky [Formation of musical thought of future music's teacher in the process of instrumental training] : Extended abstract of candidate's thesis : 13. 00. 02. Kyiv, 18 (ukr).

9. Ovcharenko N. A. (2016). Teoretyko-metodolohichni zasady profesiinoi pidhotovky maibutnikh vchyteliv muzychnoho mystetstva do vokalno-pedahohichnoi diialnosti [Theoretic-methodical principles of professional training of Music art's teachers to vocal-pedagogic activity] : Doctor's thesis :13.00.04. Kryvyi Rih, 547 (ukr).

10. Oleksiuk O. M. (2006). Muzychna pedahohika [Musical pedagogy]. Kyiv: KNUKIM, 188 (ukr).

11. Plokhotniuk O. S. (2016). Vyznachennia pedahohichnykh umov formuvannia profesiino-tsinnisnykh oriientatsii studentiv mystetsko-pedahohichnykh spetsialnostei u protsesi muzychno-vykonavskoi diialnosti [Definition of pedagogical conditions of professional values system among the students of artistic and pedagogical specialities in the process of musical-performing activity]. Scientific Notes of Kirovohrad State Pedagogical University, (143), Kirovohrad, 66 - 70 (ukr).

12. Rojtershtejn M. I. (1988). Prakticheskaya polifoniya [Practical polyphony]. Moskva: Prosveshhenie, 158 (rus).

13. Elliott D. J. Musical Creativity (Comments to Praxial Music). Available from: http:// www.davidelliottmusic.com/praxial-music-education/musical-creativity (eng).

14. Margulis E. (2012). Musical Repetition Detection Across Multiple Exposures. Music Perception : Ann Interdisciplinary Journal, 29 (4), 377-385, DOI:10.1525 / mp.2012.29.4.377 (eng).

\section{СПЕЦИФИКА ПРОФЕССИОНАЛЬНОЙ ПОДГОТОВКИ БУДУЩИХ УЧИТЕЛЕЙ МУЗЫКАЛЬНОГО ИСКУССТВА К ИНСТРУМЕНТАЛЬНО-ИСПОЛНИТЕЛЬСКОЙ ДЕЯТЕЛЬНОСТИ}

Касилов Иван, преподаватель кафедры музыковедения, инструментальной и хореографической подготовки, Криворожский государственный педагогический университет, пр-т Гагарина 54, 50086 г. Кривой Рог, Украина, kasilov1980@i.ua

В статье раскрываются основные проблемы профессиональной подготовки будущих учителей музыкального искусства к инструментально-исполнительской деятельности в условиях высшего педагогического образования в Украине. Автором статьи разрабатьваются основные специфические черты, которье входят в структуру инструментально-исполнительской деятельности при изучении специальных дисциплин в классе основного и дополнительного музыкальных инструментов в процессе обучения на факультете искусств государственных педагогических университетов. В статье рассматривается также суть понятия инструментально-исполнительской деятельности в работах известных зарубежных и отечественных ученых.

Ключевые слова: инструментально-исполнительская деятельность; исполнитель; музыкальный инструмент; профессиональная подготовка; процесс обучения; спеиифические черты; учитель музыкального искусства.

\section{SPECIFICITY OF PROFESSIONAL TRAINING OF FUTURE MUSIC ART TEACHERS TO INSTRUMENTAL-PERFORMING ACTIVITY}

Kasilov Ivan, lecturer of the department of musicology, instrumental and choreographic training, Kryvyi Rih State Pedagogical University, 54Gagarin Ave., 50086 Kryvyi Rih, Ukraine, kasilov1980@i.ua

The article is devoted to main problems of professional training, concerning of instrumental-performing activity of Music Art teachers in conditions of music-pedagogic education in Ukraine. The title of the text showes necessity of consideration and detailed analysis this problem in research works of well-known authors also.

The article begins with a short discussion, relatively of understanding of instrumental-performing activity as a contemporary pedagogic problem in the system of higher education. The introductory part deals with necessity of 
implementation of global reforms in the content of Ukrainian pedagogic education. The problem of orientation of Ukrainian society to democratic values in the conditions of joining to the Bologna agreement is considered.

The aim of the article is to determine of specificity of instrumental-performing activity as the optimal methodology, directed to resolution of complex music-performing tasks.

The next paragraph describes the main methodical ways, directed to resolution of the problem questions, concerning of instrumental-performing activity in terms of professional training of Music Art teachers at the pedagogic universities. Further the author reports that structure of instrumental-performing activity consists from next specific features, such as: physiologic peculiarity of performing apparatus; formation of performer's polyphonic thinking; systematic training during playing the musical instrument; gradual complication of music repertoire; use of various styles and genres in the process of professional training.

According to the text, contemporary higher education should to resolve the tasks, directed to development of student's personal music abilities as a future teacher-musician.

The final paragraph ends with conclusion, which generalizes importance of use of all specific features of instrumental-performing activity for attainment of positive results in the process of professional training of future Music Art teachers at the educational system of pedagogic universities.

Keywords: educational process; instrumental-performing activity; musical instrument; performer; professional training; specific features; teacher of Music Art.

Стаття надійшла до редакції 10.04.2017 Прийнято до друку 25.05.2017

УДК 378.147:7.012-051

Володимир Томашевський ORCID iD 0000-0002-9849-8569

кандидат педагогічних наук, доцент, завідувач кафедри декоративно-прикладного мистецтва та дизайну, ДВН3 «Криворізький державний педагогічний університет», вул. Мистецька, 9, 50050 м. Кривий Ріг, Україна v.tomashevsky@meta.ua

\section{ПЕДАГОГІЧНІ УМОВИ ФОРМУВАННЯ ЕСТЕТИЧНОЇ КУЛЬТУРИ МАЙБУТНІХ ДИЗАЙНЕРІВ У ВИЩИХ НАВЧАЛЬНИХ ЗАКЛАДАХ}

Стаття присвячена аналізу існуючого в науково-дослідній літературі стану щодо теоретичного обгрунтування організащійних питань, пов'язаних зі реалізачією у вищій школі певних педагогічних дій, що спрямовані на формування естетичної культури майбутніх дизайнерів, загального аналізу педагогічних умов формування естетичної культури майбутніх дизайнерів у вищих навчальних закладах. Серед них автором виділено такі як актуалізація естетичної культури майбутніх дизайнерів, організація їх естетичної освіти, залучення студентів-дизайнерів до естетизачї навколишнього середовщща та оволодіння майбутніми дизайнерами досвідом самоорганізачї естетичної культури.

Ключові слова: актуалізація; досвід самоорганізацї; естетична культура; залучення до естетизацї навколишнього середовища; педагогічні умови.

Вступ. На сьогодні в умовах реформування вищої освіти в Україні актуальними стають питання системних змін в середині як спеціальних, так і галузевих освітніх процесів, перегляду стратегічних напрямів роботи ВНЗ, спрямованості на усвідомлення кінцевого результату, модернізацію та удосконалення шляхів та методів досягнення мети навчання. Йдеться про обгрунтування на концептуальному рівні проблеми формування естетичної культури та визначення вихідних позицій щодо організації цього процесу у вищих навчальних закла- дах, серед яких з'ясування педагогічних умов формування естетичної культури майбутніх дизайнерів посідає одне з найважливіших місць.

Аналіз останніх досліджень та публікацій засвідчив, що різні аспекти формування естетичної культури особистості, а саме: роль естетичної освіти в сучасній освітньо-виховній практиці, важливість і необхідність залучення майбутніх дизайнерів до освітньо-виховного процесу в якості його суб'єктів, залежність вирішення важливих завдань освітньо-виховного змісту від якості 